\title{
Documentos
}

Justo A. Facio (1859-1931) fue un ilustre intelectual, pedagogo y escritor. Además de una notable labor en el campo de la educación costarricense (por la que llegó a ser incluso Secretario de Instrucción Pública), emprendió una obra en el periodismo cultural y político. Fundó y dirigió diarios y revistas; en ellos dejó páginas de singular valor sobre educación, sobre política, sobre arte y literatura. En este número recogemos una célebre «Carta literaria» que Facio publicó en Athenea, revista que durante tres años codirigió con el poeta Rogelio Sotela. Quizá constituya el primer escrito, con voluntad informativa y sistematizadora a la vez, que describe la trayectoria y la situación de entonces de las letras costarricenses; se refiere, en palabras del propio autor, a «el cultivo del arte teatral, de la novela y de la crítica entre nosotros».

Para su trabajo de graduación en la Escuela de Literatura y Ciencias del Lenguaje, la profesora Lenis Abarca Monge reunió en 2006 prácticamente la totalidad de la obra de Facio, no publicada en forma de libro; de tan rica recopilación LETRAS extrae este valioso documento. Para su trabajo, la profesora Abarca hizo profusas anotaciones, que figuran al pie; de ellas se han extraído las que hemos considerado esenciales, con la autorización de la autora, lo que consigna y agradece la Dirección de esta revista. La «Carta literaria» figura en el número 7, del tomo II de 1918, de Athenea, entre las páginas 432 y 444 . 


\section{Carta literaria}

San José, a 15 de junio de 1918

Señor don Simón Eliet ${ }^{1}$,

Panamá

Muy señor mío; al contestar a su estimable carta de diciembre último, debo comenzar por rogarle que perdone mi tardanza, hija solo de la falta de tiempo, en cumplir con este deber de cortesía. Por este mismo motivo no podré dar a Ud. informe tan amplio como el que desea sobre el cultivo del arte teatral, de la novela y de la crítica entre nosotros. Como en todos los países jóvenes, el teatro puede decirse que no ha nacido aún en Costa Rica, por más que una que otra vez, se hayan compuesto aquí piezas destinadas a la representación. El fenómeno es, en verdad, corriente, pues el teatro no surge en ninguna parte sino como fruto de una civilización que ha alcanzado pleno desarrollo. Parece necesario, en efecto, que las sociedades lleguen a la madurez, en otras palabras, a la edad adulta, para que los hombres se preocupen por el espectáculo variadísimo que ellas of recen y que en el teatro halla entonces un órgano de representación proporcionado a su magnitud y a su complejidad. Antes, es decir, en los primeros años de la vida, parece el ánimo más sensible a las inquietudes interiores y personales, y en el canto lírico es en donde éstas encuentran su natural y adecuado medio de expresión. Así se explica que el teatro sea la manifestación literaria última en aparecer en los dominios del arte, por lo menos en adquirir vida propia y llegar a su plenitud. Por esto, si bien la producción teatral cuenta aquí con algunas obras apreciables, ella no

Simón Eliet (1899-1953), periodista que desarrolló una importante labor en Panamá. 
puede de ser estudiada en conjunto como exponente característico de la modalidad literaria cuya forma ha adoptado.

Curioso ha de resultar sin duda que yo principie esta ligera investigación sobre el teatro costarricense hablándole de un antecesor mío, oriundo también de esa república: don Víctor de la Guardia, fundador de la familia que aquí lleva ese apellido, ilustrado por hombres cuya personalidad se destaca con notorio relieve en distintos órdenes de la vida. ${ }^{2}$ Este don Víctor de la Guardia, (hermano de mi bisabuelo don Eduardo de la Guardia), nació en Penonomé, en marzo de 1772; ingresó en la carrera administrativa de la colonia, sirvió diversos cargos en el virreinato de Santa Fe y luego en Nicaragua, de donde se trasladó al departamento de Guanacaste, lugar de su residencia definitiva. La obra por la cual debe figurar don Víctor de la Guardia como primero en esta galería costarricense es una tragedia que tiene por título La política del mundo, escrita en 1809 como parte de una fiesta que debía celebrarse en honor del nuevo rey de las Españas de Fernando el VII. Ocurre el episodio en tiempos de Julio César, que en él hace el papel de protagonista: Julio César es allí como la figura representativa de Napoleón I, tirano de «España: es, pues, una pieza alegórica». Copio en este lugar parte de lo que Ricardo Fernández Guardia, bisnieto del autor, dice en el prólogo puesto por él a la obra, editada aquí a sus expensas en 1902. «No trataré de hacer juicio crítico de La política del mundo he dicho ya que la publico tan sólo a título de curiosidad literaria: lo cual no quiere decir que la obra carezca de méritos...» etc. Yo también hago aquí esta cita, como Ud. ha de suponer por lo que el caso tiene de curioso, ya que en don Víctor de la Guardia, es decir, en un hijo de Panamá, habríamos de ver, si a ello nos pusiéramos, el precursor lejano y, sin duda, reconocido para la mayoría, de los que, andando el tiempo, han entretenido por acá sus ocios

? Hay que tener en cuenta que Facio nació en Santiago de Veragua, entonces territorio colombiano. Fue hijo de Justo Facio Carrasco y Natividad de la Guardia. A sus dos años de edad, su familia se radicó definitivamente en Costa Rica, donde se naturalizó (N. de la E.). 
en componer fábulas teatrales. Ud. de entonces a hoy, Talía y Melpómene han dado un vuelo de muchos años sin aterrizar en Costa Rica.

A la pluma de Ricardo Fernández Guardia, escritor de estilo naturalmente pulcro y muy elegante, a quien acabo de referirme, se debe una comedia de corte francés moderno, en la cual el autor se propone reproducir costumbres de nuestra alta sociedad; pero si bien en Magdalena, (ese es su nombre), hay en juego costumbres propias del país, no me parece que éstas se hallen muy bien caracterizadas en la obra; por lo menos, lo esencialmente típico queda a veces ahogado entre el follaje de lo general; sólo que esto no disminuye el encanto que allí, como en todo lo que toca, pone con su donaire este galano prosista.

Don Carlos Gagini, escritor de estilo castigado con rigor académico, ha compuesto una zarzuela, (el libreto, se entiende), El marqués de Talamanca, y algunos juguetes cómicos, a todos los cuales yo osaría poner el mismo reparo que ya le hice a Magdalena. El episodio que en El marqués de Talamanca se reproduce pertenece a la época de la colonia y está calcado en un suceso histórico cuyo actor principal es bien conocido; pero en la presentación total de la obra no hay nada que refleje la época en ninguno de sus aspectos.

Daniel Ureña, ausente hace tiempo del país, es un poeta costarricense, de oficio tipográfico (el arte no es aun aquí medio proficuo de subsistencia); tal vez en su cultura literaria se noten algunos cuantos vacíos; pero hay en él inspiración evidente, sentimiento del arte, (un poco vago, quizás), cualidades que se perciben en su poesía, curada de afeites retóricos. Ureña ha ensayado su pluma en diversos modos del arte teatral: María del Rosario, drama en tres actos y en prosa: Sombra y luz, juguete dramático en un acto y en verso; San José ale gre, revista cómica nacional, en un acto y también en verso, etc. Todas estas piezas han sido representadas en teatros de San José. Gustó mucho la revista cómica San José alegre, llena de picante intención. Seguramente el crítico encontraría sin gran esfuerzo no pocos reparos que hacerle a la obra dramática de Ureña; pero no le seria difícil tampoco señalar con el rosado color de la simpatía los lugares no escasos en que, como un gajo de arte, florece el acierto. 
Eduardo Calsamiglia, a quien en este acápite le presento, es un poeta de numen y un humorista muy ingenioso, que ha escrito varios juguetes para el teatro, (Un pecado mortal, Las opiniones de San Pedro, Resoluciones extremas. etc.), y también algunos dramas, entre ellos, El combate. Calsamiglia tiene un donaire y una picardía que se insinúan sin esfuerzo, por el solo poder de su gracia cautivadora. Es, asimismo, muy hábil en el arte de dialogar y de componer versos que, a pesar de la rima, tan ocasionada a mistificaciones y a dislocamientos de sentido, siempre dicen lo que él se propone decir, sin menoscabo de la propiedad y lo que es más valioso todavía, sin daño de la exactitud en lo tocante a los fueros de la idea.

He aquí ahora un escritor costarricense, Ernesto Martín ${ }^{3}$, cuyo talento literario puede ejercitarse con idéntica brillantez, como a ello se ponga en todos los géneros. Un cerebro nutrido de ideas, como un bosque, de maderas preciosas; un alto y seguro dominio de las formas artísticas; un verbo que corre con fluidez y entre cuyos chorros cristalinos juguetean las imágenes, todo esto, que, sin embargo, sólo representa en él tres elementos de su múltiple potencia creadora, dota a Martín de una capacidad con la cual enseñorea todos los reinos del arte, cuyos tesoros puede explotar a si arbitrio. En lo que él, sin embargo, se ha complacido particularmente es en trabajarla rica veta de la oratoria, porque Martín es, antes que todo, un orador, un orador de tipo moderno, dicho sea también en honor suyo: su elocuencia se desliza serenamente, como un brazo de mar; no hay en ella aquellos desbordamientos verbales que otrora tendían a producir efectos de avalancha en los auditorios desconcertados. Pero me aparto un punto de mi propósito y voy a pegar otra vez la hebra para decir que el teatro costarricense le ha anotado en sus modestos libros una valiosa partida de Ernesto Martín: es una comedia en dos actos y en prosa que se titula

Emesto Martín (1879-1950). En la Historia de la literatura costarricense, de Abelardo Bonilla, aparece como Emesto Martén. Abogado, escritor y orador. En 1898 publicó el libro Prosa compuesto por dieciséis artículos en prosa relacionados con diversos temas como inteligencia, facilidad y cultura. En 1918 reúne en un tomo Palabras dichas, trece artículos de discursos para el teatro. Además escribió una obra titulada Cuento de amor estrenada y publicada en 1913. 
Cuento de amor; está bellamente concebida; los personajes, que confabulan quizás demasiado bien, gastan, en cambio, muy al pelo, los modismos y formas de expresión de uso corriente entre nosotros.

Entre un grupo de cabezas jóvenes se recorta el perfil picaresco de una mujer María Isabel Carvajal, Carmen Lira en el mundo de las letras, dulce y expresivo seudónimo con el cual es nombrada familiarmente por amigos y admiradores y que en gran manera conviene a lo delicado de su temperamento artístico. A Carmen Lira le debe nuestro teatro un juguete cómico sentimental titulado; Había una vez..., en varias ocasiones representado por niños, siempre con muy buen éxito. Es una graciosa piececilla que la autora ha sazonado con aromáticos condimentos de la tierruca, dándole en característico y grato sabor local. ${ }^{4}$

En colaboración, Carmen Lira y Francisco Soler ${ }^{5}$ (de quien, así comprende ella, hablaré de aquí a poco), han escrito un diálogo en que actúan como interlocutores Pierrot, Colombina, Arlequín y Polichinela. No es verdad una obra para representada y bien merece el nombre de pasatiempo que sus autores le han dado. Rigurosamente, pues, no cabe en esta enumeración; pero la he incluido, porque hay en ella un hábil juego de diálogo, que anuncia aptitud en la esgrima de las ideas; esto sin hacer alto en los donaires que triunf an sobre el sentimentalismo amanerado y convencional a quepor ley están sujetos los episodios en que intervienen Pierrots y Colombinas; por más que este mismo Paco Soler, (así lo llamamos aquí familiarmente), diga en alguna otra parte que «Pierrot es, en la leyenda, la imaginaria manifestación del hombre libre». Este lindo pasatiempo lleva por mote ¡La ilusión eres tú! Y fue publicado con ilustraciones del joven pintor costarricense Carlos Herrero, cuya capacidad artística hemos admirado en diversas creaciones de su lápiz y de su pincel.

Producto de dos inteligencias aunadas es igualmente una comedia en dos actos y en prosa, escrita por Paco Soler, ahora en colaboración

Esta obra se publicó posteriormente con el título de Evocación, en Ariel, XII (1939): 989 ss. Francisco Soler (1839-1920). Autor de la breve novela El resplandor del ocaso (1918), y la obra teatral El último madrigal (1918), y La ilusión eres tú, a la que se refiere Facio. 
con Camilo Cruz Santos, Hay en la prosa de esa comedia, me parece a mí, un artístico desparpajo; en cuanto a los pensamientos, yo diría que éstos se mueven en ella con una gracia picante. Los autores han esbozado en La iniciación, (tal es el título de la obra), las vicisitudes de una vida que se rebela resueltamente contra el despotismo de preocupaciones a que la sociedad vive esclavizada desde hace ya bastantes centurias; el joven que así se encara con lo vulgar y lo falso que quiere regular sus actuaciones por normas un tanto audaces, pero, sin duda, conformes con la naturaleza de las cosas y con la noble independencia del espíritu. Creo ver en esa obra, aunque seguramente no hay en ella intento de imitación, las sugestiones revolucionarias de Ibsen y de Bjørson, empeñados en libertar el mundo de los convencionalismos que lo empequeñecen y que detienen el vuelo de las almas a regiones menos artificiosas y más puras de convivencia.

De todos los escritores costarricenses, éste de quien voy a hablar aquí es el que con más cariño por su obra, con más perseverancia en su empeño y con más fe en su propia vocación ha abordado la escena: se llama José Fabio Garnier ${ }^{6}$; fue educado en Italia. Por lo general o por lo exótico de su concepción, las producciones teatrales de Garnier no pertenecen a literatura determinada; no se ha propuesto él, efectivamente, reproducir situaciones que correspondan a nuestra manera de ser o a nuestra mentalidad: sólo ha procurado hacer vivir sus creaciones con los soplos que vienen de todos los rumbos de la realidad: pero yo me inclino a creer que cuando por boca de sus personajes hablan las pasiones, éstas no suelen dar con la expresión, vigorosa o profunda, que exterioriza la vehemencia con que vienen de adentro o la intensidad de creciente ahogadora con que se dilatan. Entre obras teatrales de Garnier, que son varias se encuentran las siguientes: El retorno, (drama en un acto), ¡ $¡ N a d a !$, (comedia en un acto), A la sombra del amor, (drama en tres actos), Pasa el ideal, (diálogo en acto), etc. Garnier sólo escribe en prosa.

" José Fabio Garnier (1884-1956). Este escritor costarricense es autor de La primera sonrisa (1904), Laesclava (1905) y Nada (1906), tres novelas cortas, En un tomo titulado Teatro (1912) se incluyen El retomo, La última escena y Nada (que es una novela dialogada).

216 
Séanme dado mencionar aquí, siquiera sea en son de homenaje, al Dr. don Antonio Zambrana como autor de una obra teatral escrita y representada en el país hace cosa de treinticinco años; ello de suyo se dice que no lo menciono a titulo de costarricense, puesto que la gloria de esa maternidad no es sirio a Cuba a quien corresponde; pero la cita, así y todo, resulta justificada, porque el eminente cubano abrió a la juventud de aquí horizontes nuevos en el mundo de las letras, sin que por eso su obra de cultura dejara de hacerse sentir en otras regiones del pensamiento y del arte: para aleccionar a la juventud en nobles principios y en normas de belleza, su voz elocuente se dejó oír, durante siete lustros en la cátedra de derecho, en el profesorado de segunda enseñanza, en el ateneo, en la academia, en el mitin, el periódico, en el corrillo, lugares todos en donde el asiento por él ocupado tenía siempre las fulguraciones y la resonancia de una tribuna Ningún hombre de letras, nacional o extranjero, se ha adentrado tanto como éste, con el instrumento áureo de su palabra, en los ricos bosques de inteligencias juveniles. Cuando en tiempos futuros se rehaga el proceso de la cultura tica difícilmente se encontrará manifestación alguna en que se eche de ver la señal siempre luminosa de aquella influencia. Zambrana es aquí por eso el maestro por antonomasia. La obra teatral de esto escritor a que antes me he referido es un arreglo del francés titulado Eugenio Arin, «muy sencillo», (dije ya a esto mismo propósito en otra ocasión), «sin complicaciones efectistas, como esos dramas que hace ahora Capus; pero en que, además, los protagonistas hablan «Un lenguaje de sin igual hermosura poética». El drama fue representado en el Teatro Municipal, nuestro teatro de entonces, (corría el año de 1883), y despertó vivo entusiasmo entre los discípulos y admiradores del maestro, que iniciaba su noble y brillante pontificado en el dominio espiritual de las letras

En cuanto a los otros géneros, diré a Ud. que la novela si se ha cultivado aquí y que se ha cultivado con notoria predilección, particularmente la novela regional, (cuento o novela). Como talentosos cuentistas regionales han distinguido Manuel GonzálezZeledón (Magón), Claudio 
González Rucavado, Ricardo Fernández Guardia, Aquileo J. Echeverría (cuento en verso) y Joaquín García Monge.

Si bien tuvo precursores incipientes, González Zeledón fue el primero en cultivar aquí la literatura nativa, la literatura de Folkllore, a la cual of rece este joven país un no escaso venero de tradiciones y costumbres vernáculas. En sus cuentos, cuadros de fuerte realismo, (El clis de sol, Unos novios, Una vela, etc.), aparece el pueblo tico en toda su ingenua tosquedad primitiva; en sus otros relatos, (aquellos que pueden clasificarse bajo la denominación general de artículos), tales como Sin coc̀inera,-Un día de mercado, etc.; González Zeledón dibuja hábilmente, con rasgos caricaturescos, esas graciosas nimiedades de la vida ordinaria que en las costumbres tiene un vivo color local, el que dan a la cosas del terruño las condiciones ambientes y el vocabulario. De González Rucavado ${ }^{7}$ existen cuatro publicaciones que guardan relación con las cosas lugareñas: El hijo de un gamonal, Escenas costarricenses, De ayer y ¿Egoísmo? El hijo de un gamonal es el primer ensayo de novela de este autor. Allí, como en sus obras posteriores, se sitúa ya en escenario local y allí se echa de ver igualmente el poder pictórico de su pluma; en Escenas costarricenses González Rucavado describe dos costumbres tradicionales entre nosotros, las fiestas y veraneo; en ninguna de esas descripciones falta el color local, que no es tan pronunciado, me parece a mí, cuando entran en acción, discurren o confabulan los protagonistas. De ayer es una preciosa colección de cuentos cuyos héroes son niños. ¿Egoísmo? es una novela en que el autor plantea un intríngulis psicológico de posibilidad algo dudosa; pero, en todo caso, ingeniosamente desenvuelto.

Don Carlos Gagini, de quien antes he hablado, es también autor de dos colecciones de cuentos: titulase la una, que salió a la luz hace ya algunos años, Chamarasca; la otra, de aparición reciente tiene por

\footnotetext{
7 Claudio González Rucavado (1878-1928), abogado, periodista, político y prof esor. Es autor de la novela El hijo de un gamonal (1901), de Escenas costarricenses (1906) y de los cuentos De aver (1907).
} 
título Cuentos grises; en ambas, a casi todos los sucesos o narraciones se les ha dado por lugar de desarrollo alguna circunscripción geográfica del país. El número de Ariel destinado por García Monge a conmemorar el centenario de Cervantes, (abril de 1916), aporta, como contingente del señor Gagini, un cuento, titulado Don Quijote se va, que sobresale, a mi juicio, por lo original e ingenioso.

Ricardo Fernández Guardia sido sin duda el más cosmopolita de estos escritores, en cuanto toma sus asuntos de aquí y de allá, indiferentemente,(Lolita, El manantial, Laprincesa Lulú, etc.); lo que no quita que haya manejado también con singular acierto los asuntos regionales, tales como Un santo milagroso, La política, Un héroe, etc.; cuentos todos escritos con donaire y malicia propios de aquel ingenio, en quien, además, el buen decir es un don. Los cuentos de Ricardo Fernández Guardia, que es igualmente un notable historiógrafo, están coleccionados en dos volúmenes, Hojarasca y Cuentos ticos. Este último ha sido traducido al inglés.

Aquiles J. Echeverría es el poeta nacional costarricense; ya no existe; pero su producción literaria lo mantiene, sin decaer nunca, en la categoría que correspondo a un poeta representativo; la personalidad del pueblo costarricense se destaca y acentúa en el lienzo panorámico de su poesía. El alma de este poeta maravilloso era como una sensible caja sonora en que resonaba alegremente toda la ingenua y graciosa algarabía popular; de allí extraía él los elementos y modos con que en la tela fuerte de la realidad bordaba esas encantadoras escenas del hogar campesino que con tanto acierto llamó Concherías, de concho (Concepción), nombre que aquí se emplea para designar a los sencillos moradores del campo. La musa de este poeta singular es en todo una musa criolla. Vació Echeverría sus cuentos en un histórico molde: el romance, el romance de ilustre abolengo, el octosílabo, el que tiene su origen en los mismos torpes balbuceos con que se expresa el idioma adolescente en el viejo regazo del latín. Estos cuadros de costumbres han nacionales circulan profusamente en un libro que también lleva por nombre Concherías y que entre nosotros lee con 
deleite igual hombres cultos y sencillos labriegos. Aunque esto es lo más típico que nos dejó la pluma traviesa de Aquileo J. Echeverría, conviene decir que ella produjo también lindos cuentos en prosa. García Monge, que ya había publicado interesantes novelas de sabor regional, (Hijas del campo, El Moto, Abnegación, etc.), ha traído recientemente a nuestra literatura, en una nueva serie de cuadros, (Mala sombra, Tres viejos, Pere, etc.), otros tantos episodios vividos por el pueblo y que conservan en la trascripción, bellamente realzada por la mano oculta del artista, todo el color, toda la frescura y toda la gracia que tenían en el cuadro original. Es esto a mi ver lo más típico que hay, (fuera de lo de Aquileo J. Echeverría), en literatura regional costarricense. A la aparición de esta obra, alguien, que informaba al público, insinuó que García Monge habla dado en el misticismo, atribuyendo al autor de La mala sombra lo que en el relato no era sino expresión ingenua del sentir popular, porque en el alma de toda comunidad joven o algo primitiva hay siempre un sedimento de misticismo, y éste satura y colora inevitablemente las ideas y los actos que de esa, comunidad o sus individuos emanan.

Este mismo Joaquín García Monge, permítame Ud. el paréntesis es uno de los obreros intelectuales mejor inspirados más laboriosos y más fecundos que ha producido esta pequeña y generosa nación; silencioso, reposado, modestísimo, la labor por él realizada día a día es una intensa labor de cultura. Durante una larga serie de años, García Monge ha sostenido, en gran parte, a sus expensas, varias interesantes publicaciones periódicas, (Ariel, El Convivio, La Obra), en que a la juventud sólo se le of recen lecturas seleccionadas por la mano escrupulosa del buen gusto y, lo que vale mil veces más aún, lecturas a las cuales está vinculado el noble poder de evocar hermosas teorías de ideas, de esas que desfilan ante los ojos asombrados del espíritu en viaje a las tierras lejanas donde florece el ideal Como profesor, García Monge es profesor de Estado, título que obtuvo en Chile), a la vieja y desastrosa rutina ha sustituido un arte nuevo en la enseñanza del idioma, haciendo con sus alumnos un trabajo de penetración a través 
de obras literarias diferentes, a fin de estudiar en ellas las formas evolutivas del pensamiento. Pero lo más distinguido, lo más prominente en García Monge es el educador: en todas las posiciones que ha ocupado, en todos los momentos de su vida, educar, entiéndase bien, educar en el alto sentido que esta palabra tiene hoy, ha sido la dulce tarea en que siempre se ha ejercitado; sólo que el educar en él no es una actividad a que se entrega ocasionalmente, en horas determinada y por razón de oficio; en este maestro educar es la función propia de todos sus órganos intelectuales. Últimamente desempeñaba la dirección de la Escuela Normal de Costa Rica, posición de que fue inicuamente despojado, a influjo de intrigas y mezquindades lugareñas, para ser torpemente puesta en manos de hipócrita y desatentada reacción. Modesto Martínez, periodista, escribe artículos y cuentos, uno y otros de distinto carácter, que firma con diferentes seudónimos, según el curso: Pepe Ruedelabola, El Teniente Niki, El Dr. Richet, Ramiro Pérez. Este último, un viejo sesentón, ahíto de marrullerías, le refiere al público sus vicisitudes matrimoniales, relacionándolas con incidentes y sucesos de la vida social en que predomina la nota cómica, tan acentuada en estas pequeñas sociedades de los trópicos. Este modo es creación literaria de Martínez, el cual lo maneja con mucho ingenio y donosura, a fuer de inteligente y sagaz humorista. Don Ramiro Pérez es así el viejo socarrón más popular que mangonea por salones y centros sociales de aquende. Firmados por El teniente Niki, Modesto Martínez publica también cuentos o artículos de los cuales saltan hilillos de delicada ternura, semejantes a graciosos surtidores que, al descender, se desgranan en la copa del corazón, refrescando cuanto hay en torno suyo, tales como Las arañas doradas, La leyenda del príncipe, Elegía la de la palmera, La muñeca de trapo, etc.

Hasta aquí me he referido a los cuentistas que, en alguna forma, han explotado las canteras patrias; pero el país tiene también cultivadores de este género, hoy tan en boga, que se han ausentado de la heredad solariega para ir a buscar inspiraciones en otras fuentes, sobre todo, en las fuentes algo agitadas de esa psicología que introduce sus 
refinamientos y complicaciones en el alma de las sociedades modernas. En este grupo encontramos a Rómulo Tovar, Francisco Soler y a Carmen Lira.

Rómulo Tovar es un escritor que tiene el oído pronto a las sugestiones helénicas; las cláusulas de su prosa son como avenidas bordeadas por elegantes hileras de naranjos en flor, a lo largo de las cuales los pensamientos discurren con esa olímpica serenidad que las evocaciones del pasado tienen y tendrán siempre en las llanuras del Ática. Hace poco circuló aquí un volumen de cuentos suyos, (De variado sentir), que, con ser producciones de emoción y belleza, ( $E l$ grito, En el templo, El milagro de Jesús, etc.), no han relegado a penumbra aquellos otros, artículos publicados en 1913, Hércules y los pastores, proyecciones de su espíritu sobre ideas y paisajes, a cuya final se yergue La Montaña, una montaña que perfuman mirtos de Atenas y que ennoblecen cedros del Líbano.

Francisco Soler es un satírico y un cuentista; sólo que su sátira sin veneno suele ser más bien una suerte de ironía juguetona. Este don gracioso esmalta todas sus producciones, en las cuales las ironías apenas sobresalen de la tersa superficie, como finas puntas de diamante incrustadas al ras y que fulgen alegremente bajo las reverberaciones del sol. Léanse, sino, El resplandor del ocaso, La mano de fuego, Los pecados capitales, (esta última es una disertación). Decía Zola que donde él y los Goncourt y Flaubert y Maupassant y otros escritores de su tiempo no podían entrar, allí entraba Daudet con la dulce y efusiva penetración de su gracia. Sin que esto sea poner hombro con hombro al célebre autor las Cartas de mi molino y al joven escritor costarricense, tengo para mí que otro tanto cabría decir de este último con respecto a sus conmilitones de esta banda que se ejercitan en el arte de novelar. Muy de paso habléa Ud. antes de María Isabel Carvajal, o sea, Carmen Lira, seudónimo cariñosamente asociado va entre nosotros a la simpática personalidad de la escritora que se le impuso y que lo ha acreditado con su pluma .Lo que Carmen Lira escribe no son, por lo general, propiamente cuentos; es decir, narraciones de sucedidos; sus artículos 
son más bien meditaciones sobre las cosas humildes que la rodean o que ha contemplado alguna vez y que parecen musitar en su espíritu insinuaciones desbordantes de dulce y encantadora poesía. (Mi calle, Los caminos, Una elegía humilde, El pino, Vidas estériles), etc. ¿Pero es acaso que estas cosas no viven también allí, en la impasibilidad de su mutismo o de su misterio, una vida callada, profunda y poética, y no por callada, menos elocuente? Sin duda que si; sólo que para penetrar en ese reino oculto es indispensable poseer aquel alto sentido de lo bello con que Dios suele favorecer a unos pocos seres privilegiados. Tal es el caso típico de Carmen Lira. La naturaleza, efectivamente, no tiene secretos para ella, que lee sin vacilaciones en todas las páginas de ese libro grandioso. Sin duda esto mismo le permite encontrar también en el rico seno de la naturaleza, sin esfuerzo ninguno, esas semejanzas con que los artistas saben sensibilizar y embellecer las abstracciones y las sutilezas del pensamiento, que de otro modo tal vez se ofrecería deslavazado y oscuro a nuestra comprensión. Obra algo más extensa, pero del mismo carácter, es una creación por la autora titulada Las fantasías de Juan Silvestre. Juan Silvestre es un humilde, solitario y amable filósofo que con los hilos sutiles de su pensamiento, iluminado por una melancólica luz crepuscular, teje los cuadros de su sabia filosofía en lienzo a cuyo trasluz se van dibujando encantadas imágenes de ensueño y apacibles actitudes de tristeza. Daré quizás una idea más aproximada de lo que son estas dulces meditaciones si digo que en algún modo ellas coinciden con la manera de Azorín, sin que esto delate un propósito de imitación en la escritora costarricense, en cuya personalidad literaria hay fuerte impulso de iniciativas propias para que necesite meter los pies en las huellas más o menos profundas que otros han grabado sobre la arena de su camino. La dicción de Carmen Lira es a veces un poco descuidada; pero, ¡qué frescura de pensamiento! Sumergido en su lectura, parece uno hallarse en un nutrido rosal, bañado por el rocío de la mañana, en que, seducido por la variedad, por el primor y por la belleza de todas aquellas flores, no nota uno las irregularidades del suelo fecundo donde pone la planta. 
Rubén Coto $^{8}$ es otro escritor joven que, hace ya algunos días guarda inexpiable silencio, a quien la literatura patria le es deudora de un precioso contingente, representado por una colección de originales historietas reunidas bajo este título: Pañueladade cuentos, tales como No sabía que fuera prohibido sentir, Alegría de una mañana, Una rosa y un beso, Dos diamantes, etc. Estos cuentos respiran suave sincera emoción son, además, como un índice de nobles idealismos.

Carlos Jinesta ${ }^{9}$ es un estudioso joven que ha iniciado su carrera literaria con la publicación de cuentos y de fantasías en los cuales, como en Antón, El albañilito, Lily, El abuelo y otros, se advierte la labor de la mano vacilante aún, pero que ya tiene felices aciertos.

Camilo Cruz Santos ${ }^{10}$ escritor menos joven que el anterior, y más formado, también, ahora residente en Bogotá, dejó bien marcadas en las hojas de nuestras revistas las huellas de su pluma, a la vez, vigorosa y sutil, con el paso triunfal de cuentos tales como: ElBibelot, El beso de la esfinge, El señor Alcalde, etc., que dan testimonio, testimonio eficiente, de sus dotes literarios. No he podido seguir en su odisea por aquellos mundos a este obrero del arte, pero es de creerse que su producción se haya intensificado en medio tan propicio de las labores intelectuales como la cultísima capital de Colombia.

Arturo Castro Saborío cumplía apenas los veinte años cuando del dichoso hogar que le daba calor fue bruscamente arrebatado por la mano fría de los dioses, cuya vieja y deplorable predilección por los dulces ef ebos se demostraba así una vez más con olímpico egoísmo. Pero ya a esa edad la laboriosa abeja había libado en las flores del estudio y del arte miel suficiente para llenar la modesta celdilla en que

8 Rubén Coto (1882-1956). Autor de Para los gorriones (1922). Había dejado inéditos Pañuelada de cuentos y El polvo del camino; algunas de sus secciones aparecieron en revistas como Repertorio Americano, Renovación o Athenea.

9 Carlos Jinesta, (1800-1881). Autor prolífico en el campo historiográfico. Se destacan, entre muchas, crónicas literarias y cuentos como Tierra y espíritu (1930), Cromos (1931), Mar y pensamiento (1947) y Bronces de México (1949).

(1) Camilo Cruz Santos (1890-1960). Coautor (con Francisco Soler) de La iniciación (1914); además, publicó La jaula vacía (1930). 
trabajaba. Dulces gotas de esa labor inicial son las breves composiciones que de Arturo Castro Saborío nos han quedado, (Claro de luna, Con Eugenia, Ante la tumba, Luzbel, etc.), cuentos, esbozos, de crítica, imaginaciones, paisajes... en todo ello había el germen de una hermosa cosecha futura.

Debo mencionar aquí a otros cuatro inolvidables desaparecidos: don Manuel Argüello Mora ${ }^{11}$, Teodoro Quirós ${ }^{12}$, Rafael Ángel Troyo ${ }^{13}$ y Manuel de Jesús Jiménez ${ }^{14}$, los nombro en orden de defunción. El primero de estos escritores reunió en un volumen titulado Costa Rica pintoresca tradiciones, cuentos, historias y paisajes que tienen por asunto algún incidente unos menos históricos de la vida nacional; cultivó, por consiguiente, la novela histórica, (Margarita, Elisa Delmar, La trinchera, etc.); pero de don Manuel Argüello se dice que solía desfigurar un tanto los sucesos históricos, llevado por el vuelo poderoso de su fantasía a la contemplación de cosas imaginarias, en las cuales él mismo acababa por creer; pero esta apreciación provenía quizás del prejuicio que nos induce a inquirir la verdad histórica sólo a través de los informes documentales, porque el escritor costarricense narraba sucesos de su época, en algunos de los cuales él había sido actor; sólo que él los narraba con cierto desenfado, (que alcanzaba a su estilo), y no sin traer a cuento circunstancias que el historiador ha solido desdeñar hasta ahora.

Teodoro Quirós, (llamado Yoyo familiarmente, como él por lo general firmaba también sus prosas), muerto joven, cultivó el cuento

1 Manuel Argüello Mora (1834-1902). Autor de Costa Rica pintoresca (1899), La trinchera (1899) y La bella herediana (1900). Su obra completa fue publicada con el título Obras literarias e históricas (1963). Teodoro Quirós (Yoyo Quirós) (1875-1902), cultivó el cuadro de costumbres. En 1904 quedaron recogidos sus Artículos escogidos.

Rafael Ángel Troyo (1875-1910). Autor de Terracotas (1900), Ortos (1903), Corazón joven (1904) y Poemas del alma (1906). De Terracotas hay una edición anotada, de 2006, a cargo de Juan Durán Luzio. 1902 en Costa Rica en el Siglo XIX (1902). Su obra casi completa. fue publicada en dos tomos, en 1946 y en 1949, con el título de Noticias de Antaño (1946 y 1949). 
de caricatura, a lo Vital Aza ${ }^{15}$, con intención aplicada a las gentes y cosas del país. Nótanse en los artículos, que están coleccionados en un volumen, donosura sin rebuscamientos y perspicacia crítica para dar con lo cómico, como ocurre en Las peleas de gallos, Expansionismo femenino, Gente que vale, Carnaval, etc.

Rafael Ángel Troyo, muerto en el último terremoto de Cartago, era una mariposa enamorada de una estrella, París tenía una visión de las cosas lejanas, que sentía intensamente y con rara delicadeza, y hacía con la pluma filigranas de arte, de un precioso inocente, cada una de las cuales habría podido servir de asunto para un camafeo. Dejó enriquecida la literatura con varias colecciones de cuentos, exóticos en su mayor parte, Corazón joven, Ortos, Terracotas.

Manuel de Jesús Jiménez es a mi ver el más aventajado de estos escritores desaparecidos: conocedor concienzudo de la historia patria, lector incansable, que sabía rastrear en los documentos de archivo las huellas ocultas de la vida interior, con un talento literario muy vigoroso, con un estilo puro, algo arcaico, tal vez, pero siempre bello, este escritor, supo rehacer, en una serie de cuadros de costumbres nacionales, la vida de la sociedad costarriqueña en un período que abarca toda la primera mitad del siglo XIX: es la historia anecdótica de aquella época asaz interesante (Antaño, Fiestas reales, Las carreras de San Juan, El año 23, etc., etc.)

Otros escritores han cultivado la novela general, si bien localizándola en el propio lo terruño. Entre los cuentistas he citado ya a García Monge y a González Rucavado, quiera, como ya dije también, han escrito novelas. Debo ahora referirme a doña María Fernández de Tinoco, (hija del ilustre patricio don Mauro Fernández, el organizador de la enseñanza entre nosotros), escritora en cuyo estilo se sensibilizan las imágenes de la naturaleza y a quien la literatura debe, a más de artículos sueltos, una novela denominadaApaikán, en que desenvuelve un

15 Vital Aza Díaz (1851-1912). Periodista que cultivó el escrito de tipo humorístico. Es autor de comedias y de alguna poesía satírica, que publicó en periódicos españoles (Madrid cómico, Blanco y Negro). 
episodio indígena, (por ella embellecido sin desnaturalizar índole del asunto en esa trasformación de arte) de esos que pertenecen al ciclo legendario de las Américas, anterior al descubrimiento.

Jenaro Cardona ${ }^{16}$, prosista, pero que también compone versos, es quizás el escritor costarricense en quien mejor se acentúa la responsabilidad múltiple del novelista: su primera, El primo, (apareció hace ya algunos; publicada primero en San José fue editada luego en Madrid, por la casa Calleja; últimamente ha lanzado a la circulación mundial, La esfinge del sendero, novela de concepción más amplia, de factura más sólida, enviada al certamen celebrado en 1915 por el Ateneo Nacional de Buenos Aires, en que le fue adjudicado el segundo premio, en competencia con obras, sin duda notables, de muchos otros escritores. Obtuvo el primer premio en ese certamen una novela de Hugo Wast, (seudónimo de G. Martínez Zubiría), La casa de los cuervos; aunque, según opina el eminente escritor argentino Dr. Zeballos, que declaró en artículo, publicado luego de haber leído las dos obras, es la novela del escritor costarricense la que, a juicio suyo, merece el primer, lugar, y eso que Martínez Zubiría está justamente acreditado en el mundo de las letras americanas con la publicación de novelas tales como Flor de durazno, Fuente sellada, Alegre, en las que una poderosa intuición artística mueve la pluma que allí reproduce a lo vivo desgarrones de alma y paisajes de la naturaleza. Con una alta comprensión de las cosas, en La esfinge del sendero dilucida Cardona el problema del celibato sacerdotal, por el aspecto, canónico y por el aspecto humano, por más que, a mi ver, su intención novelística no sea tendenciosa. De esta novela, que tiene pasajes muy bellos, prepara en estos días una segunda edición la casa Ollendorf, de París.

También como novelista he de citar aquí a José Fabio Garnier, autor, de dos novelas cortas Laesclava, La primera sonrisa. Como Ud. sin duda habrá observado Garnier es laborioso que hace incursiones a dos los dominios de las letras, donde ha traído, entre otros productos

$16 \quad$ Jenaro Cardona (1863-1930). Autor de las novelas El primo (1905) y La esfinge del sendero (1916). 
por él elaborados, un libro de Parábolas, algunas de ellas muy felices, todas inspiradas en un alto idealismo docente.

Ricardo Jinesta, por último, es un escritor joven que, noblemente preocupado con la suerte de los que sufren por mor de Justicia, ha escrito y publicado dos novelas (Sándalo y Martelo Silió), con ánimo de provocar movimientos de regeneración en la consciencia, no siempre dañada o empedernida, de los perseguidos o condenados por ley.

La crítica sistemática no ha tenido aún cultivadores aquí: es un género harto ocasionado a sinsabores en países chicos como éste, y de ahí, sin duda, que sólo ocasionalmente sea cultivado por uno que otro; no faltan, sin embargo, escritores que posean el sano y útil don de la crítica; por ellos siempre aplicado en sus estudios con lucimiento y nobleza, tales como José Fabio Garnier, (a quien ya he presentado en otros aspectos) Alejandro Alvarado Quirós, (actual Presidente del Ateneo de Costa Rica), y Fabio Baudrit. No es que otros escritores no ostenten algún trabajo de crítica en su labor literaria, sino que son aquéllos los que con mayor frecuencia han empleado sus actividades en ese género de producción. Garnier, por ejemplo, ha publicado un volumen de estudios críticos (Perfume de belleza) en que se comenta la obra de Rodó, de Rufino Blanco Fombona, de Pedro César Dominice, de Aquileo Echeverría, de Joaquín García Monge, etc.

Bocetos se titula el libro en que Alejandro Alvarado Quirós ha reunido últimamente sus primeros estudios de crítica, los que pudiéramos llamar, en otros términos, sus estudios juveniles, (Hojarasca, Mis versos, Lisímaco Chavarría, Modesto Martínez, A la memoria de Pío Víquez, etc.) Otro volumen publicado en 1914. Bric a brac, en que, como su nombre los expresa, hay de todo, contiene también, un juicio bien documentado y más extenso sobre la obra de Aquileo J. Echeverría; aun pudiera decirse, en rigor, que los otros trabajos de este libro son igualmente de crítica, pues, aunque no sea ése el propósito en que ellos se inspiren, el cuidadoso análisis de las cuestiones allí abordadas, en su mayor parte, de política trascendente, hace que cada uno de ellos asuma el carácter dé una elucidación en que el elemento crítico 
interviene como factor principal. Posterior a estas obras es una colección de traducciones (cuentos franceses), publicados por García Monge, en un número de Ariel, con este título, que difundo delicados aromas espirituales: Lilas y resedas. Diré ahora, para completar este apunte, que en los juicios y apreciaciones de este escritor se levante siempre la mano del crítico en un noble gesto de benevolencia, de esa benevolencia que es signo de superioridad en hombres como él, dispuestos a medir y reconocer el valor del ensueño en lucha denodada con la forma rebelde. Por lo demás, Ale jandro Alvarado Quirós es un esteta que ha formado su gusto en la lectura de los buenos autores franceses, y quizás por esto hay en su estilo una encantadora y ecuánime aleación de en energía y ligereza, que a mí me hace pensar en un mozo fuerte y sanguíneo en quien los movimientos y las actitudes están suavizadas por une sonrisa que la gracia dibuja sutilmente en sus labios.

Fabio Baudrit ha acreditado su aptitud para la crítica de escuela con la publicación de varios estudios que se imponen por la sagacidad literaria, por la apreciación justa y por el criterio independiente de que dan testimonio. Estas cualidades, que, al arrimo de otras no menos nobles, constituyen fundamentalmente la facultad de la critica, se acentúan en sus trabajos sobre ¿El egoísmo?, la novela de González Rucavado a que en otra parte me referí, y sobre la brillante labor literaria de Froylán Turcios, el poeta y escritor hondureño. Sin salir nunca de una sobriedad elegante, la prosa de Fabio Baudrit es sumamente expresiva. Pero este crítico es también un humorista de mucho pesquis. Durante no corta temporada el maleante prosista entretuvo a los lectores de La Información con los cometarios pintorescos que solía tejer alrededor de las menudencias en que consumen su actividad los inocentes tartarines del trópico. Firmaba Baudrit estos chuscos artículos con el seudónimo Fox, que llegó a hacerse popular. Entretenido en quehaceres de más importancia, el muy perezoso ha abandonado ese género. Estos dos últimos escritores, es decir, Alvarado Quirós y Baudrit, han vertido al castellano un centón de cuentos 
franceses, reunidos y publicados en volumen que se titula Piedras preciosas, con nombre que corresponde muy bien a su contenido.

Para terminar estos párrafos, diré a Ud. que Moisés Vincenzi ha publicado recientemente un estudio sobre la vida obras de Roberto Brenes Mesén, una de las inteligencias mejor cultivadas y uno de los corazones mejor puestos que hay en el país Vincenzi es un joven que de los predios de la filosofía, por los cuales él discurre con confianza que es signo de fuerza, ha extraído los materiales de que se sirve para analizar y juzgar las obras que son objeto de una atención. Es una manera que atestigua la altura filosófica a que este joven estudioso y reflexivo eleva su concepción de la crítica y la seriedad que pone en su esfuerzo para ejercer dignamente esa alta función del arte literario.

Ciertamente, no sería yo justiciero, como aspiro a ser, si no inscribiera en esta galería el nombre, por muchos conceptos ilustre, del Dr. don Valeriano Fernández Ferraz. ¿Pero cómo, si esto es así, como sin duda lo es, incurro en la irreverencia de asignarle en ella el último lugar? Sencillamente porque el título con que traigo aquí al Dr. Ferraz es el que le corresponde como cultivador de la crítica, sin que con esto dicho sea de una vez; se desconozca su provechosa actuación en otros órdenes de la cultura patria. Después de todo, si algún necio o mal intencionado me hiciera, la maligna observación, a eso tal yo le contestaría que el Dr. Ferraz puede ceder su sitio en cualquier parte al más humilde, y también al más presuntuoso, diciéndole muy en lo suyo, «Sentaos, majagranzas, que adonde quiera que yo me siente, será vuestra cabecera», como, según contó Sancho en casa de los Duques, le replicó el hidalgo rico al labrador empeñado en rehusar el asiento que, de cortés, el otro le cedía en su mesa. Efectivamente, donde quiera que el Dr. Ferraz se halle, ese será el sitio de honor. Tampoco cito aquí al Dr. Ferraz, como sucedió con el Dr. Zambrana, en concepto; de costarricense: el Dr. Ferraz es de nacionalidad española; pero pronto hará medio siglo, que vive y trabaja en Costa Rica, tiempo durante al cual ni su inteligencia ni su pluma se han dado punto de reposo. Durante los primeros años de su residencia en el país y, con algunos 
intervalos, en épocas posteriores estuvo consagrado a la práctica de la educación; pero, siempre conmovido por estas nobles inquietudes, nunca, aun cuando prácticamente no ejerciera el profesorado, ha dejado de ilustrar con sus opiniones, expuestas sin ambages, los tópicos de orden educativo en cuya solución se interesaba el público. Su trabajo en este sentido fue siempre de ponderación y de crítica, particularmente en los últimos tiempos, en que ha abordado mayor variedad de temas. Creo, así pues, no equivocarme al incluir al ilustre escritor en el grupo de críticos incipientes que antes he mencionado y en el cual él, como en todo, es el maestro. Para la juventud costarricense de varias generaciones el Dr. Ferraz ha sido un noble y autorizado mentor. En este minuto de la vida, la vigorosa y amada ancianidad del sabio maestro es como uno de esos ocasos del trópico en que el sol se estaciona para dif undir calor más sua ve y más dulce y para embellecer con sus dorados reflejos las colinas de nuestra existencia. Todos sufragamos aquí porque el temblor de ese augusto poniente se mantenga en nuestro horizonte en proporción al largo radiante día de ochenta años que le ha precedido en la marcha del tiempo.

Mucho me temo que Ud. se muestra asombrado de que solo tres ramos de las letras Costa Rica haya producido tantos escritores como en esta galería aparecen; pero es que yo no tomo esta palabra en el sentido que tiene cuando con ella se designa a los profesionales de la pluma: yo llamo escritores en esta carta a aquellos costarricenses que poseen el don singular de las letras y que, ansiosos de dar vida a sus concepciones, hi jas de un espíritu elevado y culto, se ejercitan desinteresadamente en el arte de escribir. Entre estos trabajadores del arte literario son pocos, muy pocos, los que de su pluma han podido hacer un instrumento de trabajo paraganarse la subsistencia; hoy por hoy, tal vez solamente Modesto Martínez, que le ofrece al público diario delicioso alimento en las columnas de La Información. Quizás la producción literaria podría llegar a ser un sistema permanente de trabajo para algunos de estos intelectuales en países grandes y de población bien nutrida, en donde, por el progreso de la cultura, el leer 
sea ya para todos una vehemente necesidad del espíritu. Pero aquí, no; aquí se hace labor literaria únicamente por vía de culto pasatiempo, sin quitarles el hombro a los quehaceres prosaicos que nos aseguran el pan; si hay alguno a quien en mala hora se le ocurre poner cátedra de escritor, a ese tal no le queda otro camino para vivir que meterse, sable en mano, por el escabroso país de la Bohemia, que por algún lado colinda con las tierras más miserables de la Hampa. Dignos son, por consiguiente, de sincera loa estos intelectuales, (llamémoslos así, más propiamente), que, sin mezquinos afanes de lucro, labran cariñosamente su modesta heredad interior para que sus cosechas sean regalo de todos.

Aquí, como allá, la poesía de orden lírico es el género que más cultivadores tuvo en otras épocas (ahora, no); es ese un fenómeno mental que pertenece al grupo de los hechos naturales, porque la forma rítmica es un poderoso elemento de halago para las imaginaciones juveniles, y de ahí que ella sea el medio de expresión literaria preferido en la adolescencia de sociedades que no poseen aún todos los variados recursos de cultura.

Mucho más podría decir a Ud. sobre este punto, pues todo lo anterior es apenas un esbozo ligero de las actividades literarias acerca de las cuales Ud. me pide informe; pero, como ya le he manifestado, me falta tiempopara extenderme sobre ello tanto como yo quisiera. En otra carta hablaré a Ud. de los poetas costarricenses; solo agregaré hoy, para concluir, que en estos días de crisis, de una crisis que estruja todos los organismos, la producción literaria, sin embargo, se ha intensificado aquí de manera sorprendente, como si en la inquietud que nos domina, los impulsos de vitalidad creadora se sintiesen arrastrados a buscar su medio más propio de expresión en el divino arte de la palabra.

Saludo a Ud. cordialmente, le ofrezco el testimonio de mi simpatía y me complazco en suscribirme su muy atento servidor y amigo.

Justo A. Facio 